\title{
Floristic surveys of aquatic macrophytes in reservoirs in the Agreste zone of Pernambuco State, Brazil
}

\author{
LEONARDO RAFAEL CHAVES COELHO XAVIER ${ }^{1}$, TALITA OLIVEIRA ARAÚJO ${ }^{1}$, \\ PAULA REGINA FORTUNATO NASCIMENTO² and SONIA MARIA BARRETO PEREIRA ${ }^{1,3}$
}

(received: August 23, 2011; accepted: September 06, 2012)

\begin{abstract}
Floristic surveys of aquatic macrophytes in reservoirs in the Agreste zone of Pernambuco State, Brazil). We surveyed the aquatic macrophytes in reservoirs in Camocim de São Félix in the Agreste zone of Pernambuco State, Brazil. Plants were collected on a bimonthly schedule from November/2008 to May/2009 in four reservoirs, and 33 taxa distributed among 23 families were encountered. The family Cyperaceae had the greatest number of species, followed by Lemnaceae. The predominant biologic form was emergent (33.3\%) reflecting the extensive shorelines around the reservoirs analyzed.
\end{abstract}

Key words - aquatic plants, biologic forms, northeastern Brazil

\section{INTRODUCTION}

Macrophyte communities are important components of continental aquatic ecosystems, constituting significant energy stocks and participating in nutrient cycling. These plant communities demonstrate high primary productivity as the base of the food chain in these ecosystems and serve as substrates for other organisms such as algae, bacteria, and invertebrates, providing numerous microhabitats used for egg laying and protection against predators (Barko et al. 1986, Pompêo et al. 1997, Miyazaki \& Pitelli 2003).

Animal diversity is often quite high along the margins of lentic environments, principally due to the presence of aquatic macrophytes. These plants constitute a major source of organic material, significantly contribute to the overall material and energetic economy of the system (Trivinho-Strixino \& Strixino 1991, Peiró \& Alves 2004), help rid aquatic environments of pollution, and can be used as bio-indicators of water quality (Esteves 1998, Pedralli 2000).

Studies of aquatic environments are important for quantifying biodiversity and can aid conservation and rational management programs in those ecosystems (Thomaz \& Bini 2003). These studies are often quite challenging, however, as very distinct taxonomic groups are encountered in wide spectra of environments showing marked species variations and spatial distributions (Pott \& Pott 2000, Martins et al. 2003).

\footnotetext{
1. Universidade Federal Rural de Pernambuco, Departamento de Biologia, Avenida Dom Manoel de Medeiros, s/n, Dois Irmãos, 52171-900 Recife, PE, Brazil.

2. Faculdade Frassinetti do Recife, Avenida Conde da Boa Vista, 921, Boa Vista, 50060-002 Recife, PE, Brazil.

3. Correspondig author: soniabp@terra.com.br
}

In spite of efforts by many researchers, floristic surveys of the diverse vegetation types found in northeastern Brazil have not yet furnished accurate descriptions of the botanical richness of that region, and our knowledge of aquatic plant communities there is only incipient (França 2008). Research efforts already undertaken in northeastern Brazil include: Barbieri \& Pinto (1999) in Maranhão State; Matias \& Nunes (2001) and Matias et al. (2003) in Ceará State; França et al. (2003) in Bahia State; and Pedro et al. (2006) in Paraíba State.

The present work identified the aquatic macrophytes found in reservoirs within the municipality of Camocim de São Felix in the Agreste (dry forest) region of Pernambuco State, and constitutes the first descriptions and ecological observations concerning plant communities in that region.

\section{MATERIAL AND METHODS}

The present study was undertaken in the municipality of Camocim de São Félix $\left(8^{\circ} 21^{\prime} 31^{\prime \prime} \mathrm{S} \times 35^{\circ} 45^{\prime} 43^{\prime \prime} \mathrm{W}\right)$ in the Agreste meso-region (Brejo micro-region) of Pernambuco State, Brazil. The municipality borders the municipality of Sairé to the north and east, the municipalities of Bonito and São Joaquim do Monte to the south and Bezerros to the west, and is situated in the Borborema Plateau (Beltrão et al. 2005). This municipality was chosen as it has large numbers of artificial reservoirs and aquatic habitats appropriate for macrophyte development.

Four reservoirs (collecting stations) were selected: Station $1\left(8^{\circ} 22^{\prime} 23^{\prime \prime} \mathrm{S} \times 35^{\circ} 45^{\prime} 01^{\prime \prime} \mathrm{W}\right)$, located at Sítio Tanque de Piaba had a surface area of approximately $270 \mathrm{~m}^{2}$ (with approximately $70 \%$ plant cover) and was utilized for raising cattle and leisure activities; Station 2 ( $8^{\circ} 22^{\prime} 24^{\prime \prime} \mathrm{S} \times$ $35^{\circ} 45^{\prime} 02^{\prime \prime} \mathrm{W}$ ) was also located at Sítio Tanque de Piaba, with a surface area of approximately $900 \mathrm{~m}^{2}$ and $100 \%$ plant cover (and was not utilized for any economic activity); Station 3 
$\left(8^{\circ} 22^{\prime} 26^{\prime \prime} \mathrm{S} \times 35^{\circ} 44^{\prime} 50^{\prime \prime} \mathrm{W}\right)$ was also located at Sítio Tanque de Piaba, with a surface area of approximately $225 \mathrm{~m}^{2}$ and $50 \%$ plant cover (being used only for raising cattle); the reservoir of Station 4 ( $\left.8^{\circ} 21^{\prime} 45^{\prime \prime} \mathrm{S} \times 35^{\circ} 44^{\prime} 58^{\prime \prime} \mathrm{W}\right)$, located at Fazenda Palmeira, with a surface area of approximately $2350 \mathrm{~m}^{2}$ and approximately $60 \%$ plant cover, was constructed by damming the small Tanque de Piaba River (within the Sirinhaêm water basin) and is used for irrigation and for raising livestock.

Collections were made on a bimonthly basis between November/2008 and May/2009 covering both the dry (November through January) and rainy seasons (March through May). The entire areas of each of the collecting stations (reservoirs) were inventoried and the biological forms (Esteves 1998) and spatial distributions of the aquatic macrophytes were noted.

The collected plants were pressed and labeled in the field and subsequently identified by consulting the specialized literature, including Hoehne (1948), Sculthorpe (1967), Cook (1974), Cook (1996), Scremin-Dias et al. (1999), and Pott \& Pott (2000), by comparisons with identified specimens in the PEUFR herbarium at the Federal Rural University of Pernambuco and the UFP - Geraldo Muniz herbarium at the Federal University of Pernambuco, and by consulting specialists at other institutions. After identification, all of the material was deposited in the Professor Vasconcelos Sobrinho Herbarium (PEUFR).

\section{RESULTS}

Thirty-three infrageneric taxa distributed among the phyla Chlorophyta, Pteridophyta, and Magnoliophyta were identified (table 1). The latter phylum was the best represented, comprising 26 taxa belonging to 18 families ( $78.8 \%$ of the total number of species encountered). Five species of pteridophytes were encountered distributed among four families, corresponding to $15.1 \%$ of the total number of species encountered. Chlorophytes accounted for only $6.1 \%$ of the total number of species, and were represented by a single family (Charophyceae) and two species (Chara sp. and Nitella sp.). All of the species encountered in the present survey were native; Cyperus articulatus L. and Salvinia minima Baker were considered endemic from Brazil, with the latter species being the first citation for Pernambuco State.

Cyperaceae was the most species rich family (7 spp.), followed by Lemnaceae (3 spp.), Salviniaceae ( 2 spp.), and Charophyceae (2 spp.); the other families were represented by only a single species each (table 1).

Station 1 demonstrated the highest diversity, occurring six of the seven species of Cyperaceae and all of the species of the family Lemnaceae $(42.8 \%$ of the total diversity at that site) (table 1).

Salviniaceae stood out among the pteridophytes with two species, Salvinia auriculata and S. minima. The other families of this group were all represented by a single species each: Azollaceae (Azolla sp.), Parkeriaceae (Ceratopteris thalictroides), and Pteridaceae (Acrostichum danaeifolium).

Among the pteridophytes, S. auriculata was the only species encountered in all of the collection

Table 1. The occurrence of aquatic macrophytes at reservoir collection stations in the municipality of Camocim de São Felix, Pernambuco State, Brazil, and their seasonal distributions between November/2008 and May/2009. (A=amphibious; E= emergent; $\mathrm{FF}$ = fixed floating; FL = free floating; $\mathrm{SF}=$ fixed submersed; $\mathrm{SL}=$ free submersed; D.S. = dry season; R.S. = rainy season; $\mathrm{N}=$ November; $\mathrm{J}=$ January; $\mathrm{Mr}=$ March; $\mathrm{M}=$ May).

\begin{tabular}{|c|c|c|c|c|c|c|c|c|c|c|c|c|c|c|c|c|c|}
\hline \multirow{3}{*}{ Family/species } & \multirow{3}{*}{$\begin{array}{l}\text { Biological } \\
\text { form }\end{array}$} & \multicolumn{4}{|c|}{ Station 1} & \multicolumn{4}{|c|}{ Station 2} & \multicolumn{4}{|c|}{ Station 3} & \multicolumn{4}{|c|}{ Station 4} \\
\hline & & \multicolumn{2}{|c|}{ D.S. } & \multicolumn{2}{|c|}{ R.S. } & \multicolumn{2}{|c|}{ D.S. } & \multicolumn{2}{|c|}{ R.S. } & \multicolumn{2}{|c|}{ D.S. } & \multicolumn{2}{|c|}{ R.S. } & \multicolumn{2}{|c|}{ D.S. } & \multicolumn{2}{|c|}{ R.S. } \\
\hline & & $\mathrm{N}$ & $\mathrm{J}$ & $\mathrm{Mr}$ & $\mathrm{M}$ & $\mathrm{N}$ & $\mathrm{J}$ & $\mathrm{Mr}$ & M & $\mathrm{N}$ & $\mathrm{J}$ & $\mathrm{Mr}$ & $\mathrm{M}$ & $\mathrm{N}$ & $\mathrm{J}$ & $\mathrm{Mr}$ & $\mathrm{M}$ \\
\hline Charophyceae & & & & & & & & & & & & & & & & & \\
\hline Chara sp. & $\mathrm{SF}$ & $\mathrm{x}$ & - & $\mathrm{x}$ & - & - & - & - & - & - & - & - & - & - & - & - & - \\
\hline Nitella sp. & SF & - & - & - & - & - & - & - & - & $\mathrm{x}$ & $\mathrm{x}$ & $\mathrm{x}$ & $\mathrm{x}$ & - & - & - & - \\
\hline Azollaceae & & & & & & & & & & & & & & & & & \\
\hline $\begin{array}{l}\text { Azolla sp. } \\
\text { Parkeriaceae }\end{array}$ & $\mathrm{FL}$ & $\mathrm{x}$ & $\mathrm{x}$ & $\mathrm{x}$ & $\mathrm{x}$ & $\mathrm{x}$ & $\mathrm{x}$ & $\mathrm{x}$ & $\mathrm{x}$ & - & - & - & - & $\mathrm{x}$ & $\mathrm{x}$ & $\mathrm{x}$ & $\mathrm{x}$ \\
\hline $\begin{array}{l}\text { Ceratopteris thalictroides (L.) Brongn. } \\
\text { Pteridaceae }\end{array}$ & $\mathrm{E}$ & - & - & - & - & - & - & - & - & - & - & - & - & $\mathrm{x}$ & - & - & $\mathrm{x}$ \\
\hline $\begin{array}{l}\text { Acrostichum danaeifolium Langsd. \& } \\
\text { Fisch. }\end{array}$ & $\mathrm{E}$ & - & - & - & - & - & - & - & - & $\mathrm{x}$ & $\mathrm{x}$ & $\mathrm{x}$ & $\mathrm{x}$ & $\mathrm{x}$ & $\mathrm{x}$ & $\mathrm{x}$ & $\mathrm{x}$ \\
\hline Salviniaceae & & & & & & & & & & & & & & & & & \\
\hline Salvinia auriculata Aubl. & FL & $\mathrm{x}$ & $\mathrm{x}$ & $\mathrm{x}$ & $\mathrm{x}$ & $\mathrm{x}$ & $\mathrm{x}$ & $\mathrm{x}$ & $\mathrm{x}$ & $\mathrm{x}$ & $\mathrm{x}$ & $\mathrm{x}$ & $\mathrm{x}$ & $\mathrm{x}$ & $\mathrm{x}$ & $\mathrm{x}$ & $\mathrm{x}$ \\
\hline Salvinia minima Baker & $\mathrm{FL}$ & - & - & - & - & - & - & - & $\mathrm{x}$ & - & - & - & - & - & - & - & - \\
\hline
\end{tabular}




\begin{tabular}{|c|c|c|c|c|c|c|c|c|c|c|c|c|c|c|c|c|c|}
\hline \multirow{3}{*}{ Family/species } & \multirow{3}{*}{$\begin{array}{l}\text { Biological } \\
\text { form }\end{array}$} & \multicolumn{4}{|c|}{ Station 1} & \multicolumn{4}{|c|}{ Station 2} & \multicolumn{4}{|c|}{ Station 3} & \multicolumn{4}{|c|}{ Station 4} \\
\hline & & \multicolumn{2}{|c|}{ D.S. } & \multicolumn{2}{|c|}{ R.S. } & \multicolumn{2}{|c|}{ D.S. } & \multicolumn{2}{|c|}{ R.S. } & \multicolumn{2}{|c|}{ D.S. } & \multicolumn{2}{|c|}{ R.S. } & \multicolumn{2}{|c|}{ D.S. } & \multicolumn{2}{|c|}{ R.S. } \\
\hline & & $\mathrm{N}$ & $\mathrm{J}$ & $\mathrm{Mr}$ & $\mathrm{M}$ & $\mathrm{N}$ & $\mathrm{J}$ & $\mathrm{Mr}$ & $\bar{M}$ & $\mathrm{~N}$ & $\mathrm{~J}$ & $\mathrm{Mr}$ & $\mathrm{M}$ & $\mathrm{N}$ & $\mathrm{J}$ & $\mathrm{Mr}$ & M \\
\hline Apiaceae & & & & & & & & & & & & & & & & & \\
\hline $\begin{array}{l}\text { Hydrocotyle ranunculoides L.f. } \\
\text { Araceae }\end{array}$ & $\mathrm{E}$ & - & - & - & - & $\mathrm{x}$ & $\mathrm{x}$ & $\mathrm{x}$ & $\mathrm{x}$ & - & - & - & - & $\mathrm{x}$ & $\mathrm{x}$ & $\mathrm{x}$ & $\mathrm{x}$ \\
\hline $\begin{array}{l}\text { Pistia stratiotes L. } \\
\text { Cabombaceae }\end{array}$ & $\mathrm{FL}$ & $\mathrm{x}$ & $\mathrm{x}$ & $\mathrm{x}$ & $\mathrm{x}$ & $\mathrm{x}$ & $\mathrm{x}$ & $\mathrm{x}$ & $\mathrm{x}$ & - & - & - & - & - & - & - & - \\
\hline $\begin{array}{l}\text { Cabomba aquatica Aubl. } \\
\text { Commelinaceae }\end{array}$ & SF & $\mathrm{x}$ & $\mathrm{x}$ & $\mathrm{x}$ & $\mathrm{x}$ & - & - & - & - & - & - & - & - & - & - & - & - \\
\hline $\begin{array}{l}\text { Commelina erecta } \mathrm{L} \text {. } \\
\text { Cyperaceae }\end{array}$ & A & $\mathrm{x}$ & $\mathrm{x}$ & $\mathrm{x}$ & $\mathrm{x}$ & $\mathrm{x}$ & $\mathrm{x}$ & $\mathrm{x}$ & $\mathrm{x}$ & $\mathrm{x}$ & $\mathrm{x}$ & $\mathrm{x}$ & $\mathrm{x}$ & $\mathrm{x}$ & $\mathrm{X}$ & - & - \\
\hline Cyperus articulatus L. & $\mathrm{E}$ & $\mathrm{x}$ & $\mathrm{x}$ & $\mathrm{x}$ & $\mathrm{x}$ & - & - & - & - & - & - & - & - & $\mathrm{x}$ & $\mathrm{x}$ & $\mathrm{X}$ & $\mathrm{x}$ \\
\hline Cyperus odoratus L. & $\mathrm{A}$ & $\mathrm{x}$ & $\mathrm{x}$ & $\mathrm{x}$ & $\mathrm{x}$ & $\mathrm{x}$ & $\mathrm{x}$ & $\mathrm{x}$ & $\mathrm{x}$ & $\mathrm{x}$ & $\mathrm{x}$ & $\mathrm{x}$ & $\mathrm{x}$ & - & - & - & - \\
\hline Cyperus papyrus L. & $\mathrm{E}$ & - & - & - & - & - & - & - & - & $\mathrm{x}$ & $\mathrm{x}$ & $\mathrm{x}$ & $\mathrm{x}$ & - & - & - & - \\
\hline $\begin{array}{l}\text { Eleocharis acutangula (Roxb.) } \\
\text { Schult. }\end{array}$ & $\mathrm{E}$ & $\mathrm{x}$ & $\mathrm{x}$ & $\mathrm{x}$ & $\mathrm{x}$ & $\mathrm{x}$ & - & - & - & $\mathrm{x}$ & $\mathrm{x}$ & $\mathrm{x}$ & $\mathrm{x}$ & $\mathrm{x}$ & $\mathrm{x}$ & - & - \\
\hline $\begin{array}{l}\text { Eleocharis geniculata (L.) Roem. \& } \\
\text { Schult. }\end{array}$ & $\mathrm{A}$ & $\mathrm{x}$ & $\mathrm{X}$ & $\mathrm{x}$ & $\mathrm{x}$ & - & - & - & - & $\mathrm{X}$ & $\mathrm{x}$ & $\mathrm{X}$ & $\mathrm{X}$ & $\mathrm{X}$ & $\mathrm{X}$ & - & - \\
\hline Fuirena umbellata Rottb. & $\mathrm{A}$ & $\mathrm{x}$ & $\mathrm{X}$ & $\mathrm{X}$ & $\mathrm{x}$ & - & - & - & - & $\mathrm{x}$ & $\mathrm{x}$ & $\mathrm{X}$ & $\mathrm{X}$ & - & - & - & - \\
\hline $\begin{array}{l}\text { Oxycaryum cubense } \\
\text { (Poepp. \& Kunth) Lye }\end{array}$ & $\mathrm{E}$ & $\mathrm{x}$ & $\mathrm{X}$ & $\mathrm{X}$ & $\mathrm{X}$ & $\mathrm{x}$ & $\mathrm{X}$ & $\mathrm{X}$ & $\mathrm{X}$ & $\mathrm{X}$ & $\mathrm{X}$ & $\mathrm{X}$ & $\mathrm{X}$ & - & - & - & - \\
\hline Hydrocharitaceae & & & & & & & & & & & & & & & & & \\
\hline $\begin{array}{l}\text { Egeria densa Planch. } \\
\text { Lemnaceae }\end{array}$ & SF & - & $\mathrm{X}$ & $\mathrm{X}$ & $\mathrm{x}$ & - & - & - & - & - & - & - & - & - & - & - & - \\
\hline Lemna sp. & FL & $\mathrm{X}$ & $\mathrm{X}$ & $\mathrm{X}$ & $\mathrm{X}$ & $\mathrm{X}$ & $\mathrm{X}$ & $\mathrm{X}$ & $\mathrm{X}$ & - & - & - & - & - & - & - & - \\
\hline Wolffiella sp. & FL & $\mathrm{x}$ & $\mathrm{x}$ & $\mathrm{x}$ & - & $\mathrm{x}$ & $\mathrm{x}$ & $\mathrm{x}$ & $\mathrm{x}$ & - & - & - & - & - & - & - & - \\
\hline $\begin{array}{l}\text { Wolffiella oblonga (Phil.) Hegelm. } \\
\text { Lentibulariaceae }\end{array}$ & FL & $\mathrm{x}$ & $\mathrm{x}$ & $\mathrm{x}$ & $\mathrm{x}$ & $\mathrm{x}$ & $\mathrm{x}$ & $\mathrm{X}$ & $\mathrm{x}$ & - & - & - & - & - & - & - & - \\
\hline $\begin{array}{l}\text { Utricularia gibba L. } \\
\text { Limnocharitaceae }\end{array}$ & $\mathrm{SL}$ & - & - & - & - & - & - & $\mathrm{x}$ & - & $\mathrm{x}$ & $\mathrm{x}$ & $\mathrm{x}$ & - & - & - & - & - \\
\hline $\begin{array}{l}\text { Hydrocleys parviflora Seub. } \\
\text { Menyanthaceae }\end{array}$ & $\mathrm{FF}$ & $\mathrm{x}$ & $\mathrm{x}$ & $\mathrm{x}$ & $\mathrm{x}$ & - & - & - & - & - & - & - & - & - & - & - & - \\
\hline $\begin{array}{l}\text { Nymphoides indica (L.) Kuntze } \\
\text { Nymphaeaceae }\end{array}$ & $\mathrm{A}$ & - & - & - & - & - & - & - & - & $\mathrm{x}$ & $\mathrm{x}$ & $\mathrm{X}$ & $\mathrm{x}$ & - & - & - & - \\
\hline $\begin{array}{l}\text { Nymphaea ampla (Salisb.) DC. } \\
\text { Onagraceae }\end{array}$ & $\mathrm{FF}$ & $\mathrm{x}$ & $\mathrm{x}$ & $\mathrm{x}$ & $\mathrm{x}$ & - & - & - & $\mathrm{x}$ & $\mathrm{x}$ & $\mathrm{x}$ & $\mathrm{x}$ & $\mathrm{x}$ & $\mathrm{x}$ & $\mathrm{x}$ & - & - \\
\hline $\begin{array}{l}\text { Ludwigia leptocarpa (Nutt.) H.Hara } \\
\text { Orchidaceae }\end{array}$ & $\mathrm{E}$ & $\mathrm{x}$ & $\mathrm{x}$ & $\mathrm{x}$ & $\mathrm{x}$ & $\mathrm{x}$ & $\mathrm{x}$ & $\mathrm{X}$ & $\mathrm{X}$ & $\mathrm{x}$ & $\mathrm{x}$ & $\mathrm{x}$ & $\mathrm{x}$ & $\mathrm{X}$ & $\mathrm{x}$ & $\mathrm{X}$ & $\mathrm{x}$ \\
\hline $\begin{array}{l}\text { Habenaria pratensis } \\
\text { (Salzm. ex Lindl.) Rchb.f. }\end{array}$ & $\mathrm{E}$ & - & - & - & - & - & - & - & - & - & - & - & - & $\mathrm{x}$ & - & - & - \\
\hline Poaceae & & & & & & & & & & & & & & & & & \\
\hline $\begin{array}{l}\text { Brachiaria sp. } \\
\text { Polygonaceae }\end{array}$ & A & $\mathrm{x}$ & $\mathrm{x}$ & $\mathrm{x}$ & $\mathrm{x}$ & $\mathrm{X}$ & $\mathrm{x}$ & $\mathrm{x}$ & $\mathrm{X}$ & $\mathrm{X}$ & $\mathrm{x}$ & $\mathrm{x}$ & $\mathrm{x}$ & $\mathrm{x}$ & $\mathrm{x}$ & $\mathrm{x}$ & $\mathrm{x}$ \\
\hline $\begin{array}{l}\text { Polygonum ferrugineum Wedd. } \\
\text { Pontederiaceae }\end{array}$ & E & - & - & - & - & - & - & - & $\mathrm{x}$ & - & - & - & - & $\mathrm{x}$ & $\mathrm{x}$ & $\mathrm{x}$ & $\mathrm{x}$ \\
\hline $\begin{array}{l}\text { Eichhornia crassipes (Mart.) Solms } \\
\text { Scrophulariaceae }\end{array}$ & FL & - & - & - & - & - & - & - & - & - & - & - & - & $\mathrm{x}$ & $\mathrm{x}$ & $\mathrm{x}$ & $\mathrm{x}$ \\
\hline $\begin{array}{l}\text { Lindernia rotundifolia (L.) Alston } \\
\text { Typhaceae }\end{array}$ & A & - & - & - & - & - & - & $\mathrm{x}$ & - & - & - & - & - & - & - & - & - \\
\hline Typha domingensis Pers. & $\mathrm{E}$ & $\mathrm{x}$ & $\mathrm{x}$ & $\mathrm{x}$ & $\mathrm{x}$ & $\mathrm{x}$ & $\mathrm{x}$ & $\mathrm{x}$ & $\mathrm{x}$ & $\mathrm{x}$ & $\mathrm{X}$ & $\mathrm{x}$ & $\mathrm{x}$ & $\mathrm{x}$ & $\mathrm{x}$ & $\mathrm{x}$ & $\mathrm{x}$ \\
\hline Total & & 20 & 20 & 21 & 19 & 14 & 13 & 14 & 16 & 17 & 16 & 16 & 15 & 16 & 14 & 10 & 11 \\
\hline
\end{tabular}


stations during the study period. A number of species of Magnoliophyta were likewise found in all of the collection points: Brachiaria sp. (Poaceae), Ludwigia leptocarpa (Onagraceae), Typha domingensis (Typhaeaceae), Commelina erecta (Commelinaceae), and Nymphaea ampla (Nymphaeaceae). The species occurring in only a single collection stations were: Chara sp., Cabomba aquatica, Egeria densa, and Hydrocleys parviflora (Station 1); Salvinia minima (Station 2); Lindernia rotundifolia, Nymphoides indica, Cyperus papyrus, and Nitella sp. (Station 3); Eichhornia crassipes, $H$. pratensis, and $C$. thalictroides (Station 4). Station 1 demonstrated the largest number of species $(n=21$, corresponding to $63.6 \%$ of all species collected). Stations 2 and 3 each had 17 species, representing $51.5 \%$ of the total diversity encountered; 16 species were collected at Station 4, corresponding to $48.5 \%$ of the total.

Most of the species were encountered during both the rainy and dry seasons, although Commelina erecta, Nymphaea ampla, Eleocharis acutangula, E. geniculata, and Habenaria pratensis were not found at Station 4 during the rainy period; $S$. minima, $N$. ampla, Utricularia gibba, and Polygonum ferrugineum were only found at Station 2 during the rainy period, while E. acutangula was only collected during the dry period. Lindernia rotundifolia was only collected at Station 3 during the dry period.

Emergent macrophytes dominated among the specimens collected (11 species; $33.3 \%$ of the total), followed by free-floating ( 8 species; $24.2 \%$ ) and amphibious forms ( 7 species; 21.2\%). The least represented forms were fixed-submerged (4 species; 12.1\%), fixed-floating (2 species; $6.1 \%$ ), and free-submerged (1 species; $3 \%$ ). In spite of the occurrence of larger numbers of emergent species, free-floating plants occurred more frequently at three collection stations: S. auriculata (Station 1), Pistia stratiotes (Station 2), and Eichhornia crassipes (Station 4).

Station 2 demonstrated marked occurrences of $P$. stratiotes (floating habit) and Oxycarium cubensis and Ludwigia leptocarpa (emergent habit), which formed floating islands that developed over organic material derived from the dead and decomposing remains of P. stratiotes and Utricularia gibba (or over living specimens of these same macrophytes). O. cubensis and L. leptocarpa occurred at Station 3, associated with $U$. gibba (free-submerged habit). Floating islands of these species were also observed at this collection point.

\section{DISCUSSION}

The species richness of aquatic macrophytes encountered in the reservoirs at Camocim de São Felix was inferior to other locations previously examined in Brazil: Pedralli et al. (1993) recorded 134 aquatic macrophyte species distributed among 52 families at the Estação de Pesquisa e Desenvolvimento Ambiental de Peti in Minas Gerais State (MG); Bove et al. (2003) reported 113 species of aquatic macrophytes distributed among 40 families in temporary aquatic ecosystems on the coastal plains of Rio de Janeiro State; França et al. (2003) recorded the occurrence of 121 species distributed among 46 families in their analysis of the vascular flora in reservoirs in the semiarid region of Bahia State; and Costa Neto et al. (2007) listed 162 species of aquatic macrophytes belonging to 68 families in a study of the flora of the Lagos do Amapá region. Other researchers, however, have reported lower diversity levels than those encountered in the present study: Reis \& Barbosa (1993) encountered only 14 aquatic macrophytes species in Mares Lake in the municipality of Lagoa Santa (MG); Bini et al. (2005) identified 16 taxa in the Cachoeira Dourada reservoir (GO/MG); while Pedro et al. (2006) reported the occurrence of only nine species while examining the dynamics of macrophyte occupation of reservoirs in the semiarid region of Bahia State.

These differences in species richnesses among various published studies may largely be due to: a) the inclusion, by some authors, of riparian species that occupy terrestrial habitats immediately adjacent to lentic environments; b) the inventory sites having very different surface areas; c) differences in collection efforts. Paz \& Bove (2007) noted that the presence of certain species in aquatic environments does not necessarily imply their dependence on standing water, but rather their tolerance to flooding for short periods of time; their presence in these sites may simply be the consequence of accidental flooding and/or the occupation of uncovered sites during the dry season (considered tolerant plants by these authors).

In terms of the numbers species per family, many authors have reported the dominance of the Cyperaceae at collection sites: a high diversity of Cyperaceae and Poaceae (a total of 87 species, $13 \%$ of the total for each family) was seen in the Jericoacoara Environmental Protection Area in Ceará State (Matias \& Nunes 2001); $15.5 \%$ of the 35 macrophyte species identified at the Itaipu Reservoir were members of the Cyperaceae (Thomaz et al. 2003a); and of the 35 species of macrophytes encountered in the Poconé swamp in Mato Grosso State, $28.6 \%$ were members of Cyperaceae (Rebellato \& Cunha 2005). Kita \& Sousa (2003), however, found Poaceae (15.7\%) to be the most well represented family in Figueira Lake, in Parana State. 
The great diversity of Cyperaceae species reflects their efficient vegetative propagation by complex subterranean systems composed of rhizomes and tubercular roots, with many species also having subterranean stolons. This family has an important role in stabilizing sediments, particularly along lake and river margins, and has been used in the recomposition of altered sites (Matias et al. 2003). Dense growths of Cyperaceae species are likewise seen along the coast of Brazil, growing on humid soils rich in minerals and organic material (Tavares et al. 2007).

In terms of the biological forms of macrophytes, Thomaz et al. (2002) and Agostinho et al. (2000) reported that $60 \%$ and $66.7 \%$, respectively, of the total numbers of lentic species were emergent - similar to the results reported here (33.3\%). Other authors, however, reported high representations of amphibious forms (Thomaz et al. 2003b, Paz \& Bove 2007). Nymphoides indica was considered by Bove et al. (2003) to be an exclusively aquatic species, although we encountered it flowering along the margins of Station 3, and therefore considered it to be an amphibious species. The capacity of this plant to adapt to different environments demonstrates its accentuated ecological plasticity that is often reflected in morphological modifications (Esteves 1998).

The occurrence of Egeria densa at Station 1 may be explained by the high penetration of sunlight at that site during the period in which the floating macrophyte Salvinia auriculata did not dominate the reservoir surface. This observation is supported by laboratory experiments with Egeria najas Planchon conducted by Travechio \& Thomaz (2003) that demonstrated that subsurface photosynthetically active radiation stimulated biomass increases.

In relation to the floating mats of macrophyte vegetation observed at Stations 2 and 3 in the present work, Pivari et al. (2008) noted that some of their characteristics, such as substrate type and floristic composition, will vary according to their degree of ecological succession and that they can be considered ecotones between aquatic and terrestrial ecosystems composed of mixed vegetation forms (both aquatic and terrestrial plants).

In relation to the geographical distributions of the macrophyte species encountered at the four collection sites in the present study, a large majority of them were native and common to aquatic ecosystems in many Brazilian localities, while others demonstrate ample global distributions.

Acknowledgements - The authors thank the Conselho Nacional de Desenvolvimento Científico e Tecnológico (CNPq) and the Fundação de Amparo à Ciência e Tecnologia do Estado de Pernambuco (Facepe) for their financial support, as well as the Departamento de Biologia da Universidade Federal Rural de Pernambuco for their logistical and financial support during the field collections.

\section{REFERENCES}

Agostinho AA, Thomaz SM, Minte-Vera SV, Winemiller KO. 2000. Biodiversity in the high Paraná river floodplain. In Biodiversity in wetlands: assessment, function and conservation (B Gopal, W Junk, JA Davis, eds.). Backhuys Publishers, Leiden, v.1, p.89-118.

Barbieri R, Pinto MCP. 1999. Study on the aquatic vegetation in the São Bento County - Baixada Maranhense (Maranhão, Brasil). Boletim do Laboratório de Hidrobiologia 12:95-105.

Barko JW, Adams MS, Clesceri NL. 1986. Environmental factors and their consideration in the management of submersed aquatic vegetation: a review. Journal of Aquatic Plant Management 24:1-10.

Beltrão BA, Mascarenhas JC, Miranda JLF, Souza Junior LC, Galvão MJTG, Pereiras N. 2005. Diagnóstico do município de Camocim de São Félix. Projeto cadastro de fontes de abastecimento por água subterrânea estado de Pernambuco. Ministério de Minas e Energia. CPRM/ PRODEEM, Recife.

Bini LM, Oliveira LG, Souza DC, Carvalho P, Pinto MP. 2005. Patterns of the aquatic macrophyte cover in cachoeira Dourada Reservoir (GO-MG). Brazilian Journal of Biology 65:19-24.

Bove CP, Gil ASB, Moreira CB, Anjos RFB. 2003. Hidrófitas fanerogâmicas de ecossistemas aquáticos temporários da planície costeira do estado do Rio de Janeiro, Brasil. Acta Botanica Brasilica 17: 119-135.

Cook CDK. 1996. Aquatic and wetland plants of India. Oxford University Press, New York.

Cook CDK. 1974. Water plants of the world. Dr. W. Junk Publishers, The Hague.

Costa Neto SV, Senna CSF, Tostes LCL, Silva SRM. 2007. Macrófitas aquáticas das regiões dos lagos do Amapá, Brasil. Revista Brasileira de Biociências 5: 618-620.

Esteves FA. 1998. Fundamentos de limnologia. Interciência/ Finep, Rio de Janeiro.

França F, Melo E, Góes Neto A, Araújo D, Bezerra MG, Ramos HM, Castro I, Gomes D. 2003. Flora vascular de açudes de uma região de semi-árido da Bahia, Brasil. Acta Botanica Brasilica 17:549-559.

França F. 2008. O estudo de angiospermas aquáticas vasculares no Nordeste brasileiro. In Anais do 59응 Congresso Nacional de Botânica. Rio Grande do Norte, Sociedade Botânica do Brasil, Natal, p.435-436.

Hoehne FC. 1948. Plantas aquáticas. Secretaria de Agricultura de São Paulo, São Paulo. 
Kita KK, Souza MC. 2003. Levantamento florístico e fitofisionomia da lagoa Figueira e seu entorno, planície alagável do alto rio Paraná, Porto Rico, estado do Paraná, Brasil. Acta Scientiarum, Biological Sciences 25:145-155.

Martins D, Velini ED, Piteli RA, Tomazella MS, Negrisoli E. 2003. Ocorrência de plantas aquáticas nos reservatórios da Ligth- RG. Planta Daninha 21:105-108.

Matias LQ, Amado ER, Nunes EP. 2003. Macrófitas aquáticas da lagoa de Jijoca de Jericoacoara, Ceará, Brasil. Acta Botanica Brasilica 17:623-631.

Matias LQ, Nunes EP. 2001. Levantamento florístico da área de proteção ambiental de Jericoacoara, Ceará. Acta Botanica Brasilica 15:35-43.

Miyazaki DMY, Pitelli RA. 2003. Estudo do potencial do pacu (Piaractus mesopotamicus) como agente de controle biológico de Egeria densa, E. najas e Ceratophyllum demersum. Planta Daninha 21:53-59.

Paz J, Bove CP. 2007. Hidrófitas vasculares da lagoa de Carapebus, Parque Nacional da Restinga de Jurubatiba, Rio de Janeiro, Brasil. Revista Brasileira de Biociências 5:495-497.

Pedralli G. 2000. Padrões florísticos como subsídios à conservação da biodiversidade de macrófitas aquáticas. In Tópicos atuais em Botânica. (TB Cavalcanti, BMT Walter, orgs.) 1a ed., Embrapa Recursos Genéticos e Biotecnologia, Brasília, v.1, p.335-339.

Pedralli G, Stehmann JR, Teixeira MCB, Oliveira VL, Meyer ST. 1993. Levantamento da vegetação aquática ("macrófitas") na área da EPAD - Peti, Santa Bárbara, MG. Iheringia, Série Botânica 43:15-28.

Pedro F, Maltchik L, Bianchini Junior I. 2006. Hydrologic cycle and dynamics of aquatic macrophytes in two intermittent rivers of the semi-arid region of Brazil. Brazilian Journal of Biology 66:575-585.

Peiró DF, Alves, RG. 2004. Levantamento preliminar da entomofauna associada a macrófitas aquáticas da região litoral de ambientes lênticos. Uniara 15:177-188.

Pivari MO, Pott VJ, Pott A. 2008. Macrófitas aquáticas de ilhas flutuantes (baceiros) nas sub-regiões do Abobral e Miranda, Pantanal, MS, Brasil. Acta Botanica Brasilica 22:563-571.

Pompêo MLM, Henry R, Moschini-Carlos V, Padovani C. 1997. A influência da macrófita aquática Echinochloa polystachya (H.B.K.) Hitchcock nas características físicas e químicas da água na zona de desembocadura do rio Paranapanema na represa de Jurumirim, SP. Revista Brasileira de Ecologia 1:44-53.

Pott VJ, Pott A. 2000. Plantas aquáticas do Pantanal. Embrapa, Brasília.

Pott VJ, Cervi AC. 1999. A familia Lemnaceae Gray no Pantanal (Mato Grosso e Mato Grosso do Sul), Brasil. Revista Brasileira de Botânica 22:153-174.
Rebellato L, Cunha CN. 2005. Efeito do "fluxo sazonal mínimo da inundação" sobre a composição e estrutura de um campo inundável no Pantanal de Poconé, MT, Brasil. Acta Botanica Brasilica 19: 789-799.

Reis SPW, Barbosa FAR. 1993. Estudo da composição de macrófitas aquáticas da lagoa dos Mares, município de Lagoa Santa, com ênfase em aspectos ecológicos de Salvinia herzogii Aubl. Acta Limnologica Brasiliensis 6:196-208.

Scremin-Dias E, Pott VJ, Hora RG, Souza PR. 1999. Nos jardins submersos da Bodoquena: guia para identificação de plantas aquáticas de Bonito e região. Editora Universidade Federal do Mato Grosso do Sul, Campo Grande.

Sculthorpe CD. 1967. The biology of aquatic vascular plants. St. Martins Press, New York.

Strixino G, Trivinho-Strixino S. 1991. Chironomidae (Diptera) associados a sedimentos de reservatórios: significado dos diferentes povoamentos. In Anais do VI Seminário Regional de Ecologia. Universidade Federal de São Carlos, São Carlos, v.6, p.151-168.

Tavares AS, Araújo AC, Guimarães FB. 2007. Cyperaceae ocorrentes na Baixada do Maciambú, Parque Estadual da Serra do Tabuleiro, Palhoça, SC. Revista Brasileira de Biociências 5:186-188.

Thomaz DO, Costa Neto SV, Tostes LCL. 2003b. Inventário florístico das ressacas das bacias do Igarapé da Fortaleza e do Rio Curiaú. In Diagnóstico das ressacas do Estado do Amapá: bacias do Igarapé da Fortaleza e Rio Curiaú. (SV Costa Neto, LCL Tostes, DO Thomaz, eds.). CPAQ/IEPA e DGEO/SEMA, Macapá, p.1-22.

Thomas SM, Bini LM. 2003. Análise crítica dos estudos sobre macrófitas aquáticas desenvolvidos no Brasil. In Ecologia e manejo de macrófitas aquáticas (SM Thomas, LM Bini, eds.). Editora da Universidade Estadual de Maringá, Maringá, p.19-38.

Thomaz SM, Pagioro TA, Bini LM, Souza DC. 2002. Macrófitas aquáticas da planície de inundação do Alto Rio Paraná: listagem de espécies e padrões de diversidade em ampla escala. In Relatório Peld/CNPq/ Nupelia, Maringá, p.187-191.

Thomaz SM, Souza DC, Bini LM. 2003a. Species richness and beta diversity of aquatic macrophytes in a large subtropical reservoir (Itaipu Reservoir, Brazil): the influence of limnology and morphometry. Hydrobiologia 505:119-128.

Travechio WLG, Thomas SM. 2003. Effects of light on the growth and photosynthesis of Egeria najas Planchon. Brazilian Archives of Biology and Technology 46: 203-209. 